\title{
Broken Trust. Confidence Gaps and Distrust in Latin America
}

\author{
Paolo Parra Saiani ${ }^{1}$ (D) Enrico Ivaldi ${ }^{2,3} \cdot$ Andrea Ciacci $^{3,4} \cdot$ Lucia Di Stefano $^{1}$
}

Accepted: 5 September 2021

(c) The Author(s) 2021

\begin{abstract}
Latin American societies show lower levels of political trust when compared to other regions of the world. The lack of trust in institutions can led to ineffective management of public affairs, social crises, lack of transparency, economic problems and even difficulties in countering pandemics. The objective of this work is to build an index (LADI) that provides a measure of the level of perceived distrust in the institutions of the different Latin American countries and its variations over the period from 2008 to 2018. The data used for this analysis are of a subjective nature and come from the series of surveys provided by Latinobarómetro. To develop the analysis, we have used a quantitative approach of a partially non-compensatory aggregative type, known as Adjusted Mazziotta and Pareto Index. The results show a generalized increase of distrust in the years 2017 and 2018 for several Latin American countries. On the other hand, in countries where the rule of law is more consolidated, a best perception of the functioning of democracy emerges.
\end{abstract}

Keywords Institutional trust · Government · Latin America · Aggregative method · Temporal index

\section{Introduction}

In recent years, there has been a renewed interest in the so-called "confidence gaps", which would constitute threats to the legitimacy of democratic institutions and obstacles to economic growth. Trust has been considered as a central dimension of social capital, a necessary condition of social integration, economic efficiency, and democratic stability (Arrow, 1972; Coleman, 1988; Putnam, 1993, 2000; Fukuyama, 1995; Newton, 1997); trust can be defined as the set of socially learned expectations that people have regarding to other

Paolo Parra Saiani

paolo.parra.saiani@unige.it

1 Department of Political Sciences, University of Genoa, Genoa, Italy

2 Department of Political Sciences, C.I.E.L.I., the Italian Centre of Excellence on Logistics Transports and Infrastructures, University of Genoa, Genoa, Italy

3 Centro de Investigaciones en Econometría - CIE University of Buenos Aires, Buenos Aires, Argentina

4 Department of Economics, Center for Security, Risk and Vulnerability, University of Genoa, Genoa, Italy 
individuals, to organizations and institutions, and to the moral and social order. The concept of trust is related to expectations that have a positive value for the social actor and which are formulated in conditions of uncertainty. This applies both when the receiver of such expectations is the natural and social organisation as a whole or its individual institutional and collective expressions (systemic or impersonal trust), and when the receiver is made up of individual actors (personal or interpersonal trust) (Rotter, 1980; Misztal, 1996; Frederiksen, 2014). While the concept of trust is referred to both kinds of relations, it is necessary to differentiate them: if intersubjective trust has to do with the contingency associated with the agency of the other, the institutional trust deals with performance and reliability (Luhmann, 1988; Seligman, 1997; Hardin, 2002).

Compared to interpersonal trust, the mechanisms of systemic and institutional trust are less studied. Economic crisis often aggravates the conditions in which local governments have to manage territories, with an impact on local quality of life. The quality of life at local level can be one of the determinants of trust or distrust in the institutions: "if individuals perceive government as having a primarily negative impact on their quality of life, a reluctance to trust government is a likely outcome" (Yonk \& Smith, 2018). The level of this uncertainty is the complex product of several factors: "Normally, trust is a response to good institutional performance, but it is also an essential condition for effective governance. It is the basis for compliance with the rules. Trust in political institutions not only encourages citizens to pay taxes or to support reforms that require short-term costs, in view of long-term benefits" (Mingo \& Faggiano, 2020), but may save lives: as Elgar, Stefaniak and Wohl have pointed out recently, "confidence in institutional authorities and low-income inequality may facilitate public health advice [...]. Specifically, vaccination rates may differ between countries as a function of income inequality and social capital. In summary, our analysis found that COVID-19 mortality relates to income inequality and specific dimensions of social capital after other cross-national differences in wealth, population size, and population age were controlled" (2020). Marlow et al. (2007), van der Weerd et al. (2011) and Ozawa and Stack (2013) reach the same conclusions.

The distance created between the actor and the system favours the perception of an absence of alternatives (Simmel, 1900; Luhmann, 1988). Institutional trust is widespread in many countries and represents the feeling of de-legitimization that is considerably involving a wide range of social and political institutions: institutions are then seen as far from citizens' needs and expectations. Like in Wright (1976) or Hart (1978), distrust is not always the product of ignorance and unrealism or a reaction to mass society: some dose of distrust in institutions "may be a healthy sign of citizens' aloofness from a sphere of social life on which they have little control" (Moisés, 2006; see also Pettit, 1998; Sztompka, 1999; Warren, 2001). The prevalence of deprived and powerless social groups among those who express political distrust shows that it is the result of rational and realistic attitudes. The heterogeneity of these groups, their fatalism, and their willingness to pragmatically accept the status quo mean that the negative attitude towards the political system is not translated into effective opposition. The more complex societies are, the more generalised is the need for both interpersonal and institutional trust, since there is a significant positive correlation between trust in oneself and others, and trust in institutions (Erikson, 1968; Lipset \& Schneider, 1983; Newton \& Norris, 2000; Allum et al., 2010).

As Warren argues (1999), there is a strong connection between democracy and trust, saying that they are distinct but complementary ways of making collective decisions and organizing collective actions. Trusting institutions is not the same thing as trusting individuals. In addition, institutions are like bicycles, because they cannot be the objects of genuine trust, but only the objects of empirical or theoretical knowledge and beliefs (Ibidem). 
Remembering also that institutional trust can be seen as a result of individual's limited information, Offe (1996) suggests strategies that can address the deficit of trust in institutions. Trust can increase if institutions develop norms of truth-telling, solidarity, promise-keeping, but also develop the habits and dispositions of extending trust to strangers by increasing citizen involvement in associational life.

The aim of this paper is to construct an index, called Latin American Distrust Index (LADI) that provides a measure of the perceived distrust level toward the institutions of the different Latin American countries. LADI enables one to capture the variations over the time period 2008-2018. To pursue the aims, the subjective data provided by Latinobarómetro surveys are used. The analysis is based on the development and application of a partially non-compensatory aggregative quantitative method, known as Adjusted Mazziotta and Pareto Index (AMPI).

This paper intends to contribute to literature in several ways. Mainly, it expands the extent knowledge in the field of the trust phenomenon towards the Latin American countries institutions from a political-sociological perspective. Second, it shows how the quantitative methods of analysis, and in this specific case the AMPI method, can be employed in different fields of research effectively. Third, it proposes a cross-contribution dealing with a delicate issue, i.e. trust in institutions. Such a theme is prone to be deepened from different analytical perspective in further work in different disciplines, given the pervasive effects that high or low levels of trust can produce in the broad frame of a country-system.

\section{Data}

The data used in this analysis come from Latinobarómetro surveys. ${ }^{1}$ We have adopted the sample of Latin American countries to acquire the perceived level of distrust towards institutions in the Latin American Region. Data are of a subjective nature. They are expressed as a percentage frequency and represent the percentage of respondents who are satisfied and confident in the functioning of the different institutions. ${ }^{2}$ The data represent a historical series as they refer sequentially to several different years. In the specific, data refer to the period from 2008 to 2018. For the two-year periods 2011-12 and 2013-14 are available only two surveys, one for each two-year period. Surveys involved approximately 20,000 interviews each year, constituting — at least for the latest waves-representative samples of $100 \%$ of the population of each country. As a result, Latinobarómetro (2018a) states that surveys are representative of the region's population on the basis of stratification criteria. ${ }^{3}$

\footnotetext{
1 Latinobarómetro is a nongovernmental organization based in Santiago, Chile. Latinobarómetro administers a common questionnaire to households in Latin America with questions that involve areas such as Economy and International Trade, Integration and Regional Trading Blocks, Democracy, Politics and Institutions, Social Policies, Civic Culture, Social Capital and Social Fraud, the Environment, and Current Issues. For additional information, see www.latinobarometro.org.

${ }^{2}$ One of the main objections to building trust indices towards institutions rests on the variability of the scores assigned by respondents to what is considered an 'institution', since not all institutions are considered in the same manner by respondents. Universities and churches, for example, get high scores, while Parliament and government, much lower ones (Carballo \& Hermelo, 2021). In our article, we focus on the five items in Table 1, which usually report congruent scores.

3 Technical notes provide details of the sampling process and some information concerning the non-inclusion of some areas to which access is difficult; an example — not the only one-is given by some rural areas in Argentina (Latinobarómetro, 2018b).
} 
Table 1 Indicators description

\begin{tabular}{|c|c|}
\hline Indicator & Scale \\
\hline Satisfaction with democracy & $\begin{array}{l}\text { 1. Very satisfied 2. Rather satisfied 3. Not very satisfied } 4 \text {. Not at all } \\
\text { satisfied }-1 \text {. Don't know }-2 \text {. No answer/refused }-3 \text {. Not applicable }-4 \text {. } \\
\text { Not asked }\end{array}$ \\
\hline $\begin{array}{l}\text { Confidence in National Con- } \\
\text { gress/in Parliament }\end{array}$ & $\begin{array}{l}\text { 1. A lot of confidence } 2 \text {. Some confidence } 3 \text {. Little confidence } 4 \text {. No con- } \\
\text { fidence at all }-1 \text {. Don't know -2.- No answer/refused -4.- Not asked }\end{array}$ \\
\hline Confidence in the Judiciary & $\begin{array}{l}\text { 1. A lot of confidence } 2 \text {. Some confidence } 3 \text {. Little confidence } 4 \text {. No con- } \\
\text { fidence at all -1. Don't know -2.- No answer/refused -4.- Not asked }\end{array}$ \\
\hline Confidence in the Police & $\begin{array}{l}\text { 1. A lot of confidence } 2 \text {. Some confidence } 3 \text {. Little confidence } 4 \text {. No con- } \\
\text { fidence at all }-1 \text {. Don't know -2.- No answer/refused }-4 \text {-- Not asked }\end{array}$ \\
\hline Confidence in the Government & $\begin{array}{l}\text { 1. A lot of confidence } 2 \text {. Some confidence } 3 \text {. Little confidence } 4 \text {. No con- } \\
\text { fidence at all }-1 \text {. Don't know }-2 \text { - No answer/refused }-4 \text {.- Not asked }\end{array}$ \\
\hline
\end{tabular}

Source: Latinobarómetro (2018c)

The employed dataset is constituted by 5 indicators, described in Table 1 . The aggregation process has been developed by considering these elementary indicators.

In order to evaluate the level of distrust for each Latin American Country, it has been built a temporal index, indicated by using the acronym LADI. The direction (sign) of the index is negative. In this sense, higher LADI values correspond to higher levels of distrust.

Some indicators may be positively correlated with the phenomenon to be measured (positive polarity), whereas others may be negatively correlated with it (negative polarity); since all the indicators must have positive polarity, we reverse those with negative polarity by using the transformation proposed by Mazziotta \& Pareto (2018) for AMPI.

\section{Methods}

Starting from a formative approach (Maggino, 2017), the aim is to construct an index to evaluate the level of trust that characterizes the different Latin American countries. Adopting a formative (or causal) approach means that the elementary indicators are assumed to be cause the latent variable, instead of being caused by it. In these terms, some variations in the formative indicators change the value of the latent variable (Blalock, 1968).

The choice of the right measurement perspective should be theory-driven (Diamantopoulos \& Siguaw, 2006). In this regard, it is necessary to specify in advance what relationships characterize the theoretical framework of reference (Edwards \& Bagozzi, 2000). The formative approach choice has been previously evaluated on the basis of the nature proper of the phenomenon to be studied. Since it has been clarified that the elementary indicators employed in this study are cause of higher/lower levels of political trust, and not vice versa, the formative solution is the most suitable (Diamantopoulos \& Winklhofer, 2001).

One of the most common problems affecting the construction of indexes is the compensation resulting from the aggregation of uneven indicators, namely compositionthrough-compensation fallacy (Alaimo \& Maggino, 2020). Specifically, it refers to those situations where an index can produce the same values for different situations (Ibidem). 
In order to better explain what compensation refers to, it is necessary to clarify the meaning of "substitutable" and "non-substitutable" indicators. The former indicates the possibility to compensate a "deficit" in one indicator by a "surplus" in another (Mazziotta \& Pareto, 2017, 174) and the latter refers to the opposite situation. Compensation is often not allowed in the case of a formative approaches-based measurement, therefore indicators with different meanings don't allow the compensation (non-substitutability), since such a mathematical operation would imply the violation of their initial semantic character (Maggino, 2017). This is the reason why when dealing with the formative approach, it is important to ensure the partial non-compensability of the aggregation method.

A further limitation of most of the methods used to construct indicators is the impossibility of producing measures that are comparable over time (Mazziotta \& Pareto, 2018). The problem that arises can be summarized as follows: how can an index be produced whose values represent the evolution of a phenomenon over a given period of time?

The solution offered by Mazziotta and Pareto (2017) proposes the construction of an index aimed at the analysis of historical series and able, at the same time, to partially limit the compensatory effect deriving from the aggregation. This approach is called Adjusted Mazziotta and Pareto Index (AMPI), a variant of the Mazziotta and Pareto Index (MPI) (Mazziotta \& Pareto, 2017, 2016). Many applications of AMPI have been proposed (Alaimo et al., 2020a; Alaimo \& Maggino, 2020; Ciacci et al., 2020; D’Urso et al., 2020; Ivaldi et al., 2020a; Ivaldi \& Ciacci, 2020), because it can be employed to conduct analysis in several research fields. Another approach to building indicators comparable over time is the so-called "stacking deprivation" (Norman, 2010; Landi et al., 2018). Stacking deprivation produces more compensatory results than those produced by AMPI (Mazziotta \& Pareto, 2019).

There are also non-aggregative solutions to compare set of indicators over time (Alaimo et al., 2020b). According to this approach, a method for the analysis of time series is represented by temporal Poset (Alaimo et al., 2020a). However, many contributions have been developed on an aggregative analytical system, well established in the literature (Ciacci et al., 2021; Ciacci \& Tagliafico, 2020; Ivaldi et al., 2020b; Mazziotta \& Pareto, 2020; Penco et al., 2020; Ivaldi et al., 2018). A strength of the AMPI method is represented by the application of a penalty function to the statistical units. The amount of the penalty is related to the statistical units' variable tendency to assume even or uneven values of its indicators. The effect of the penalty is to limit the compensation deriving from the aggregation of indicators characterized by not aligned values. For these reasons, the AMPI method is the best to use.

AMPI procedure calculation is a step-by-step process (Mazziotta \& Pareto, 2018), i.e., a process developed in more phases. They are identifiable in a min-max normalization and aggregation. For the formalization of the AMPI formulas, see Mazziotta and Pareto (2018, from 968 to 970 pages).

So it is necessary to adopt the "negative" form of the AMPI index, since increasing values of the index correspond to negative variations of the phenomenon, i.e., distrust.

The AMPI procedure was important to calculate LADI index. The work on the elementary indicators (Table 1) was done without building intermediate dimensions. Given the negative polarity of all the indicators, the correct interpretation of the LADI index suggests that the higher LADI values correspond to higher levels of distrust. 


\section{Results}

Table 2 shows the scores established by the different Latin American countries with regard to the distrust over time. Starting from the first year of detection (LADI-08), the index shows high levels of perceived distrust in Peru (127.7), Panama (114.7) and Guatemala (114.48). On the other hand, a high trust in institutions is placed in Uruguay (73.75), El Salvador (88.54) and Chile (91.03).

In 2009, there were some changes in the LADI-09 ranking compared to the previous year. Peru (122.38) and Guatemala (115.99) confirmed their position as the countries with the highest levels of distrust; Nicaragua, with a LADI-09 coefficient equal to 115.02, shows a clear increase compared to $2008(+11.61)$. On the other hand, trust in Panama (89.36) has risen convincingly, and low levels of distrust of institutions El Salvador (88.72), Chile (86.53), Costa Rica (86.52) and Uruguay (67.17) are confirmed.

In 2010, the perceptions in Peru (122.04), Guatemala (121.98) and Mexico (113.46) remained almost unchanged, while the distrust grew in Dominican Republic (111.21), Bolivia (110.63) and El Salvador (104.16). On the other hand, the main decreases in the value of LADI-10 can be seen in the cases of Honduras (100.90), Argentina (99.50) and Brazil (87.85).

LADI-11-12 shows some more pronounced variations than in the previous three years. While the countries with the highest level of distrust remain the same (Guatemala (125.38), Dominican Republic (114.72) and Peru (113.46)), there is again an increase in distrust in Honduras (112.97), after the sharp decrease in LADI-10. Chile (104.78) leaps to the middle of the ranking, with a strongly growing level of distrust. Increases of distrust also emerge in Costa Rica (98.75) and Brazil (97.76), while trust in Argentina is strengthened (89.14). Ecuador is the country that more than all the others show an increase in trust $(81.51,+21.63$ compared to LADI-10).

The surveys for the years 2013-14 (LADI-13-14) and 2015 (LADI-15) show the greatest instability in the perception of trust/distrust in Latin America. Specifically, looking at LADI-13-14, Honduras (121.71) and Peru (120.58) show a strengthening of the feeling of distrust towards institutions, as well as Panama (99.32), which is settling at a lower overall level of distrust. The most noticeable change in trust can be found in Dom. Rep. (92.00, -22.72 on LADI-11-12), as well as an apparent strengthening of trust in institutions emerges in Nicaragua $(90.46,-13.43)$.

LADI-15 shows variations among the countries with the highest levels of distrust. El Salvador (116.75) acquires the little hoped-for first position for the highest level of scepticism towards democracy and its institutions. There is further accentuated growth for Brazil (111.13), the fourth country with the highest level of distrust, Panama (109.93) and Venezuela (107.26).

According to the results of LADI-16, there are no particular changes in 2016. The only change worthy of note is recorded in Mexico (96.29, - 17.06 compared to the score resulting from LADI-15).

LADI-17 shows a situation that is deeply changed, if compared with previous years, due to changes (even small ones) that have occurred incrementally over the years. The countries with the greatest perceived distrust are Paraguay (119.13), Brazil (116.56), Peru (115.58), El Salvador (113.82), Mexico (112.72). Among the countries in which respondents express the highest trust in their institutions are Argentina (92.98), Costa Rica (89.21), Nicaragua (84.12), Ecuador (80.54) and Uruguay (68.04). 


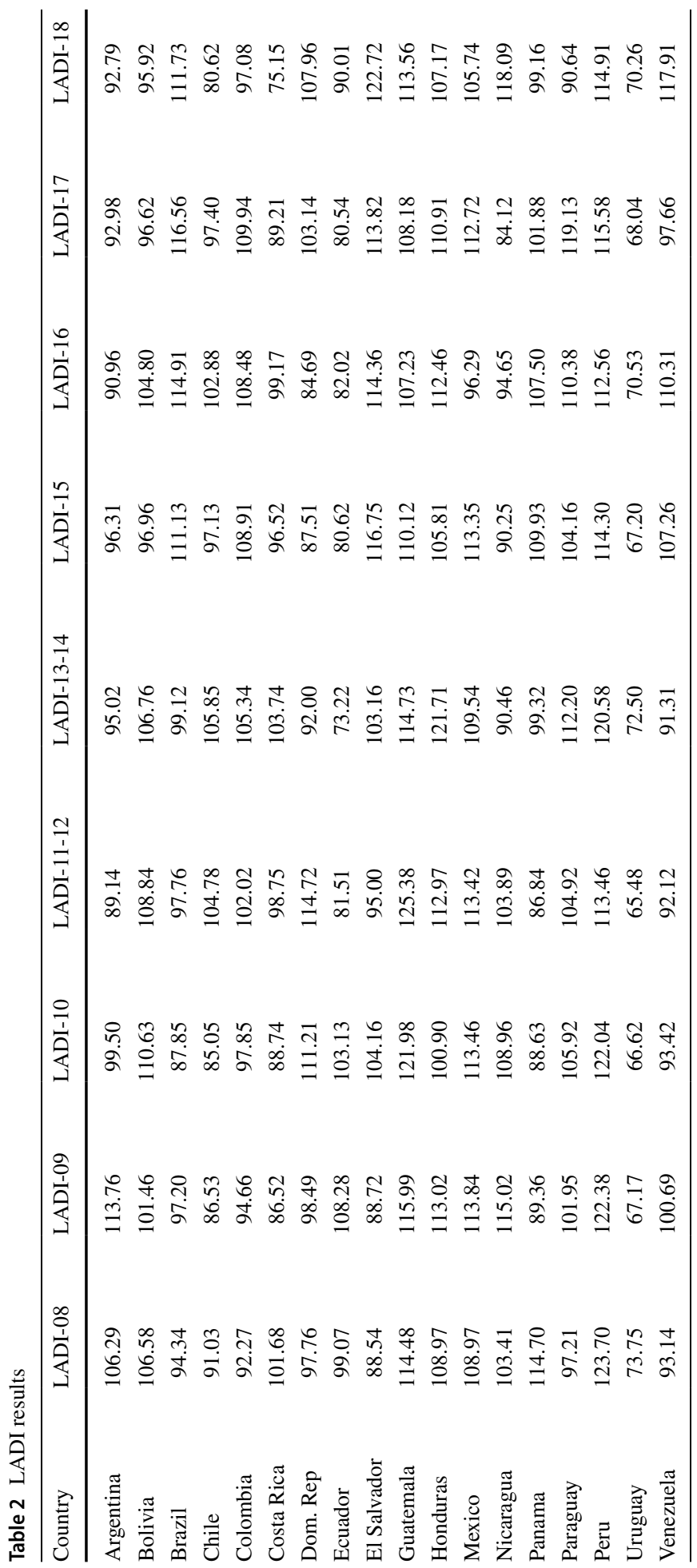




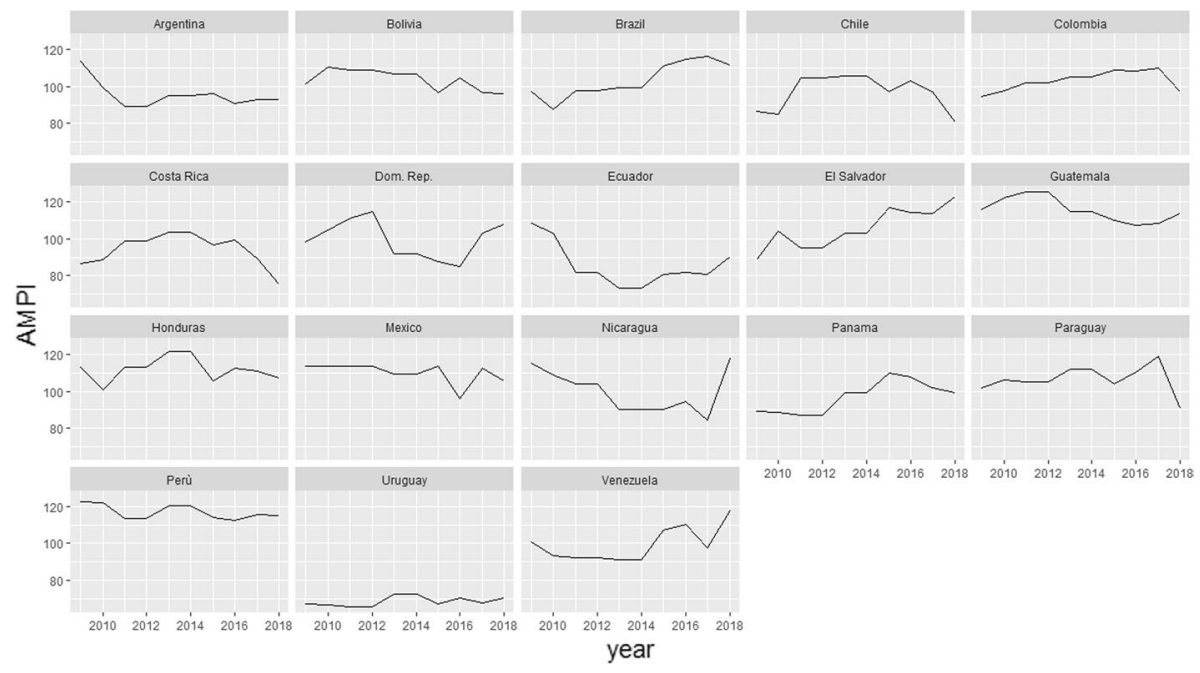

Fig. 1 Graphic representation of the time-series

LADI-18 offers a changed picture from the one initially analyzed with LADI-08. On this basis, 2018 can be identified as a year of rupture. In fact, LADI-18 shows a high variability compared to the previous year, with sudden changes in population opinion in several countries. El Salvador ranks first for its high distrust (122.72), which grew further between 2017 and 2018 (+8.89). In Nicaragua (118.09) and Venezuela (117.91) there were real upheavals, with an increase in distrust reaching a peak of +33.97 for Nicaragua and +20.26 for Venezuela. On the contrary, increases in trust would emerge convincingly in Colombia (97.08), Chile (80.62), Costa Rica (75.15) and, above all, in Paraguay (90.64, -28.49 compared to LADI-17).

Figure 1 shows the fluctuation in levels of distrust during the years for each Latin American country. With 100 being the average reference value for the LADI index, only Uruguay has levels of distrust below the average threshold for all the years observed. Argentina, starting from 2010, falls below the average threshold for all the following years. A similar result is also established by Ecuador, which reaches its minimum in the years 2013-14. Costa Rica, whose trend is mainly below the average threshold, exceeds 100 on only two occasions: 2008 and 2013-14.

On the contrary, there are some cases of prolonged distrust towards the institutions of their country: El Salvador constantly follows a trajectory of growing distrust, starting from the 2008 minimum to the 2018 maximum. Guatemala, Honduras, and Peru never fall below the threshold level, showing a deep-rooted distrust of their institutional system.

\section{Discussion and conclusions}

This paper wants to analyse the level of trust in political institutions in Latin American countries and its variations over time, from 2008 to 2018. To do this, it has been adopted a partially non-compensatory aggregative analysis method known as AMPI, obtaining an index of distrust (LADI) for each year of detection. From the values of the indices, in most cases, there are significant variations over a few years or from one year to the next. The 
picture appears mostly unstable and susceptible to shocks that can be linked to the political sphere of influence.

The years 2017 and 2018 were the years that presented the deepest inflections of trust in democracy and institutions. The situation appears to be growing sharply in the year 2017 for Brazil and Mexico. This sentiment led in 2018 to the election of two presidents with a radical orientation (Hunter \& Power, 2019), candidates with a different profile from that typically offered by the political system in the two countries. The high levels of distrust established in Honduras, and which remained almost constant throughout the decade, are to a large extent related to high crime rates (Consejo Ciudadano para la Seguridad Publica y Justicia Penal, 2011) and opaque elections, as well as a regime that resorted to alleged human rights violations (IACHR, 2019) to suppress political dissent; but it may be relevant the initial enthusiasm with which Latin American citizens received democracies during the transition, then reduced because the established democratic systems have not been able to meet the basic needs of certain social groups (Catterberg \& Moreno, 2006: 33; Delgado Sotillos, 2015, 140). Deep economic inequalities and uncertainties underlie the lack of trust in Venezuela; in addition to this, Venezuela has been torn by deep political crises, that can lead to threats to the social cohesion of the country (Morselli et al., 2020). The source of the high level of distrust measured in Peru is the corruption (Goldstein \& Drybread, 2018). In Nicaragua, where the very-controversial regime of Daniel Ortega is in force (Thaler, 2017), distrust has reappeared with a sharp increase from 2017 to 2018. By contrast, prosperous countries such as Uruguay, Costa Rica and Chile, where the rule of law is relatively well established, are the countries most satisfied with the way democracy (Kurtenbach \& Nolte, 2017) works.

As many will remember, Chile has been the scene of protests erupted in 2019-2020, and the fact that thousands and thousands of people in the streets rallied against government may seem contradictory. A possible explanation of this (apparent?) inconsistency, is that 'trust' is a polysemic concept, recalling various meanings as well as different cognitive objects, thus mixing trust in persons holding a position and the position itself (Pitrone, 2009): Chileans may still have high trust in institutions, while disagreeing with government. Another possible explanation which requires further investigation, is that "in countries where trust in institutions is low, citizens often express their consent for political candidates - not rarely populists and radicals - who promise immediate benefits and quick solutions to complex problems" (Mingo \& Faggiano, 2020; see also Kriesi et al., 2012; Del Tronco, 2013; Olivera, 2014; Kriesi \& Pappas, 2015; Morlino \& Quaranta, 2016; Muro \& Vidal, 2016; Morlino \& Raniolo, 2017; Arpino \& Obydenkova, 2019). In this case, protesters asked for a new constitution, not exactly a "quick solution" nor a solution providing "immediate benefits", so indirectly confirming that a high level of trust in institutions is plausible even in times of political crisis and unrests if configured as political participation and civic engagement (Kanacri \& Jiménez-Moya, 2017). As Lewis and Weigert pointed out, "An informed democratic citizenry, then, retains both adequate distrust of individual politicians, and an abiding trust in the political system itself" (1985).

However, the unequal trends between countries with respect to the citizen assessment of Latin American democracies and determining their causes is still a complex issue that requires analysis and specific explanatory elements in each of the countries (Delgado Sotillo, 2015, 140). As stated before, distrust is not always the product of ignorance and unrealism or a reaction to mass society, since distrust in institutions may be a rational citizens' reaction, as the prevalence of deprived and powerless social groups among those who express political distrust shows. Historical series analysis has allowed us to measure the levels of trust within the temporal range 2008-2018 for the eighteen Latin American 
countries. The use of an aggregative method has made it possible to achieve unequivocal and easily communicable results (Mazziotta \& Pareto, 2017). In order to test the validity of the results obtained, the recommendation is the use of a method different from the one used, which can reproduce the analysis proposed here for the purposes that characterize it. An interesting idea could lead to the use of a non-aggregative method functional to the analysis of historical series, such as the already mentioned method of the temporal Poset (Alaimo et al., 2020a).

Funding Open access funding provided by Università degli Studi di Genova within the CRUI-CARE Agreement. Not applicable.

Open Access This article is licensed under a Creative Commons Attribution 4.0 International License, which permits use, sharing, adaptation, distribution and reproduction in any medium or format, as long as you give appropriate credit to the original author(s) and the source, provide a link to the Creative Commons licence, and indicate if changes were made. The images or other third party material in this article are included in the article's Creative Commons licence, unless indicated otherwise in a credit line to the material. If material is not included in the article's Creative Commons licence and your intended use is not permitted by statutory regulation or exceeds the permitted use, you will need to obtain permission directly from the copyright holder. To view a copy of this licence, visit http://creativecommons.org/licenses/by/4.0/.

\section{References}

Alaimo, L. S., Arcagni, A., Fattore, M., \& Maggino, F. (2020a). Synthesis of multi-indicator system over time: A poset-based approach. Social Indicators Research. https://doi.org/10.1007/ s11205-020-02398-5

Alaimo, L. S., Ciacci, A., \& Ivaldi, E. (2020b). Measuring sustainable development by non-aggregative approach. Social Indicators Research. https://doi.org/10.1007/s11205-020-02357-0

Alaimo, L. S., \& Maggino, F. (2020). Sustainable development goals indicators at territorial level: Conceptual and methodological issues-the Italian perspective. Social Indicator Research, 147, 383-419. https://doi.org/10.1007/s11205-019-02162-4

Allum, N., Patulny, R., Read, S., Sturgis, P. (2010). Re-evaluating the links between social trust, institutional trust and civic association. In J. Stillwell, P. Norman, C. Thomas, P. Surridge (Eds.) Spatial and social disparities. Understanding Population Trends and Processes, vol. 2. Springer, Dordrecht. https://doi. org/10.1007/978-90-481-8750-8_13.

Arpino, B., \& Obydenkova, A. V. (2019). Democracy and political trust before and after the great recession 2008: The European Union and the United Nations. Social Indicators Research. https://doi.org/10. 1007/s11205-019-02204-x

Arrow, K. (1972). Gifts and exchanges. Philosophy and Public Affairs, 1(4), 343-362.

Blalock, H. M. (1968). The measurement problem: A gap between the languages of theory and research. In H. M. Blalock \& A. B. Blalock (Eds.), Methodology in social research. McGraw-Hill.

Carballo, M. \& Hermelo, M. (2021). Trust and cultural changes in Latin America, IV ISA Forum of Sociology, 26/2/2021.

Catterberg, G., \& Moreno, A. (2006). The individual bases of political trust: Trends in new and established democracies. International Journal of Public Opinion Research, 18(1), 31-48.

Ciacci, A., Ivaldi, E., Mangano, S., \& Ugolini, G. M. (2021). Environment, logistics and infrastructure: The three dimensions of influence of Italian coastal tourism. Journal of Sustainable Tourism. https://doi. org/10.1080/09669582.2021.1876715

Ciacci, A., Ivaldi, E., \& Soliani, R. (2020). A potential business environment of a smart cities: A subjective approach in strategic outlook. In H. Dinçer \& S. Yüksel (Eds.), Business and finance innovation: Multidimensional policies for emerging economies. Emerald Publishing Limited.

Ciacci, A., \& Tagliafico, G. (2020). Measuring the existence of a link between crime and social deprivation within a metropolitan area. Revista de Estudios Andaluces, 40, 58-77. https://doi.org/10.12795/rea. 2020.i40.04 
Consejo Ciudadano para la Seguridad Pública y Justicia Penal. (2011). Global study on homicide 2011. Mexico.

Coleman, J. S. (1988). Social capital in the creation of human capital. American Journal of Sociology, 94, 95-120.

D’Urso, P., Alaimo, L. S., De Giovanni, L., \& Massari, R. (2020). Well-being in the Italian regions over time. Social Indicators Research. https://doi.org/10.1007/s11205-020-02384-x

Del Tronco, J. (2013). ¿Por defecto o por defectos? Las causas de la desconfianza institucional en América Latina. Revista Latinoamericana de Opinión Pública, 3, 143-180. https://doi.org/10.14201/ rlop. 22293

Delgado Sotillos, I. (2015). Instituciones y satisfacción con la democracia. Un estudio comparado de los vínculos representativos en Latinoamérica. Revista Latinoamericana De Política Comparada, 9, $129-157$.

Diamantopoulos, A., \& Siguaw, J. A. (2006). Formative versus reflective indicators in organizational measure development: A comparison and empirical illustration. British Journal of Management, $17(4), 263-282$.

Diamantopoulos, A., \& Winklhofer, H. (2001). Index construction with formative indicators: An alternative to scale development. Journal of Marketing Research, 37, 269-277.

Edwards, J. R., \& Bagozzi, R. P. (2000). On the nature and direction of relationships between constructs and measures. Psychological Methods, 5, 155-174.

Elgar, F. J., Stefaniak, A., \& Wohl, M. J. A. (2020). The problem with trust: Time series analysis of social capital, income inequality, and COVID-19 deaths in 84 countries. Social Science and Medicine, 263, 113386. https://doi.org/10.1016/j.socscimed.2020.113365

Erikson, E. H. (1968). Identity, youth and crisis. W. W. Norton Company.

Frederiksen, M. (2014). Trust in the face of uncertainty: A qualitative study of intersubjective trust and risk. International Review of Sociology, 24(1), 130-144. https://doi.org/10.1080/03906701.2014. 894335

Fukuyama, F. (1995). Trust: The social virtues and the creation of prosperity. Hamish Hamilton.

Goldstein, D. M., \& Drybread, K. (2018). The social life of corruption in Latin America. Culture, Theory and Critique, 59(4), 299-311. https://doi.org/10.1080/14735784.2018.1531816

Hardin, R. (2002). Trust and trustworthiness. Russell Sage Foundation.

Hart, V. (1978). Distrust and democracy. Cambridge University Press.

Hunter, W., \& Power, T. J. (2019). Bolsonaro and Brazil's illiberal backlash. Journal of Democracy, $30(1), 68-82$.

Inter-American Commission on Human Rights (2019). Human rights situation in Honduras, 2019. OAS.

Ivaldi, E., Bonatti, G., \& Soliani, R. (2018). Objective and subjective health: An analysis of inequality for the European Union. Social Indicators Research, 138(3), 1279-1295.

Ivaldi, E., \& Ciacci, A. (2020). Measuring level of technological infrastructure in smart cities a noncompensatory approach in strategic priorities in competitive environments. In H. Dinçer \& S. Yüksel (Eds.), Multidimensional approaches for business success. Springer.

Ivaldi, E., Parra Saiani, P., Primosich, J. J., \& Bruzzi, C. (2020a). Health and deprivation: A new approach applied to 32 Argentinian urban areas. Social Indicators Research, 151, 155-179. https:// doi.org/10.1007/s11205-020-02369-w

Ivaldi, E., Penco, L., Isola, G., \& Musso, E. (2020b). Smart sustainable cities and the urban knowledgebased economy: A NUTS3 level analysis. Social Indicators Research, 150, 45-72. https://doi.org/ 10.1007/s11205-020-02292-0

Kanacri, B. P. L., \& Jiménez-Moya, G. (2017). Good practices on civic engagement in chile and the role of promoting prosocial behaviors in school settings. In B. García-Cabrero, A. Sandoval-Hernández, E. Treviño-Villareal, S. D. Ferráns, \& M. G. P. Martínez (Eds.), Civics and citizenship. Moral development and citizenship education. SensePublishers. https://doi.org/10.1007/978-94-6351-068-4_11

Kriesi, H., Grande, E., Dolezal, M., Helbling, M., Höglinger, D., Hutter, S., \& Wüest, B. (2012). Political conflict in Western Europe. Cambridge University Press.

Kriesi, H., \& Pappas, T. S. (Eds.). (2015). European populism in the shadow of the great recession. ECPR Press.

Kurtenbach, S., \& Nolte, D. (2017). Latin America's fight against corruption: The end of impunity. (GIGA Focus Lateinamerika, 3). Hamburg: GIGA German Institute of Global and Area StudiesLeibniz-Institut für Globale und Regionale Studien, Institut für Lateinamerika-Studien. https://nbnresolving.org/urn:nbn:de:0168-ssoar-52149-6.

Landi, S., Ivaldi, E., \& Testi, A. (2018). Measuring change over time in socio-economic deprivation and health in an urban context: The case study of Genoa. Social Indicator Research, 139(2), 745-785. https://doi.org/10.1007/s11205-017-1720-3 
Latinobarómetro. (2018a). Ficha Técnica por País Latinobarómetro 2018, https://www.latinobarometro.org.

Latinobarómetro. (2018b). Informe Metodológico Latinobarómetro 2018 Argentina, https://www.latin obarometro.org.

Latinobarómetro. (2018c). Codebook. https://www.latinobarometro.org.

Lewis, J., \& Weigert, A. (1985). Trust as a social reality. Social Forces, 63(4), 967-985. https://doi.org/ $10.2307 / 2578601$

Lipset, S. M., \& Schneider, W. (1983). The confidence gap. The Free Press.

Luhmann, N. (1988). Familiarity, confidence, trust: Problems and alternatives. In D. Gambetta (Ed.), Trust (pp. 94-107). Basil Blackwell.

Maggino, F. (2017). Developing indicators and managing the complexity. In F. Maggino (Ed.), Complexity in society: From indicators construction to their synthesis (pp. 87-114). Springer.

Marlow, L. A., Waller, J., \& Wardle, J. (2007). Trust and experience as predictors of HPV vaccine acceptance. Human Vaccines, 3(5), 171-175. https://doi.org/10.4161/hv.3.5.4310

Mazziotta, M., \& Pareto, A. (2016). On a generalized non-compensatory composite index for measuring socio-economic phenomena. Social Indicators Research, 127, 983-1003. https://doi.org/10.1007/ s11205-015-0998-2

Mazziotta, M., \& Pareto, A. (2017). Synthesis of indicators: The composite indicators approach. In F. Maggino (Ed.), Complexity in society: From indicators construction to their synthesis (pp. 161191). Springer.

Mazziotta, M., \& Pareto, A. (2018). Measuring well-being over time: The adjusted Mazziotta-Pareto index versus other non-compensatory indices. Social Indicators Research, 136, 967-976. https:// doi.org/10.1007/s11205-017-1577-5

Mazziotta, M., \& Pareto, A. (2019). Use and misuse of PCA for measuring well-being. Social Indicators Research, 142, 451-476. https://doi.org/10.1007/s11205-018-1933-0

Mazziotta, M., \& Pareto, A. (2020). Composite indices construction: The performance interval approach. Social Indicators Research. https://doi.org/10.1007/s11205-020-02336-5

Mingo, I., \& Faggiano, M. P. (2020). Trust in institutions between objective and subjective determinants: A multilevel analysis in european countries. Social Indicators Research, 151(3), 815-839.

Misztal, B. A. (1996). Trust in modern societies: The search for the bases of social order. Polity Press.

Moisés, J. Á. (2006). Citizens' distrust in democratic institutions. International Review of SociologyRevue Internationale de Sociologie, 16(3), 593-616. https://doi.org/10.1080/03906700600931418

Morlino, L., \& Quaranta, M. (2016). What is the impact of economic crisis on democracy? Evidence from Europe. International Political Science Review, 37(5), 618-633.

Morlino, L., \& Raniolo, F. (2017). The impact of the economic crisis on South European democracies. Palgrave MacMillan.

Morselli, D., Passini, S., \& McGarty, C. (2020). Sos Venezuela: An analysis of the anti-Maduro protest movements using Twitter. Social Movement Studies. https://doi.org/10.1080/14742837.2020.17700 72

Muro, D., \& Vidal, G. (2016). Political mistrust in Southern Europe since the Great Recession. Mediterranean Politics, 22(2), 197-217.

Newton, K. (1997). Social capital and democracy. American Behavioral Scientist, 40(5), 575-586. https://doi.org/10.1177/0002764297040005004

Newton, K., \& Norris, P. (2000). Confidence in public institutions: Faith, culture, or performance. In S. J. Pharr \& R. D. Putnam (Eds.), Disaffected democracies: What's troubling the trilateral countries? (pp. 52-73). Princeton University Press.

Norman, P. (2010). Identifying change over time in small area socio-economic deprivation. Applied Spatial Analysis and Policy, 3(2-3), 107-138.

Offe, C. (1996). Modernity and state: East, west. MIT Press.

Olivera, J. (2014). Changes in inequality and generalized trust in Europe. Social Indicators Research, 124(1), 21-41.

Ozawa, S., \& Stack, M. L. (2013). Public trust and vaccine acceptance-international perspectives. Human Vaccines \& Immunotherapeutics, 9(8), 1774-1778. https://doi.org/10.4161/hv.24961

Penco, L., Ivaldi, E., Bruzzi, C., \& Musso, E. (2020). Knowledge-based urban environments and entrepreneurship: Inside EU cities. Cities. https://doi.org/10.1016/j.cities.2019.102443

Pettit, P. (1998). Republican theory and political trust. In V. Braithwaite \& M. Levi (Eds.), Trust and governance. Russell Sage Foundation.

Pitrone, M. C. (2009). Sondaggi e interviste. Lo studio dell'opinione pubblica nella ricerca sociale. Franco Angeli.

Putnam, R. (1993). Making democracy work: Civic traditions in modern Italy. Princeton University Press. 
Putnam, R. D. (2000). Bowling alone: The collapse and revival of American community. New York: Simon \& Schuster.

Rotter, J. B. (1980). Interpersonal trust, trustworthiness, and gullibility. American Psychologist, 35(1), 1-7. https://doi.org/10.1037/0003-066X.35.1.1

Seligman, A. B. (1997). The problem of trust. Princeton University Press.

Simmel, G. (1900). Philosophie des geldes. Duncker \& Humblot.

Sztompka, P. (1999). Trust a sociological theory. Cambridge University Press.

Thaler, K. M. (2017). Nicaragua: A return to caudillismo. Journal of Democracy, 28(2), 157-169. https://doi.org/10.1353/jod.2017.0032

van der Weerd, W., Timmermans, D. R., Beaujean, D. J., Oudhoff, J., \& van Steenbergen, J. E. (2011). Monitoring the level of government trust, risk perception and intention of the general public to adopt protective measures during the influenza A (H1N1) pandemic in the Netherlands. BMC Public Health, 11, 575. https://doi.org/10.1186/1471-2458-11-575

Warren, M. E. (1999). Democracy and trust. Cambridge University Press.

Warren, M. E. (2001). Democratic theory and trust. In M. E. Warren (Ed.), Democracy \& trust. Cambridge University Press.

Wright, J. D. (1976). The dissent of the governed. Alienation and democracy in America. Academic Press.

Yonk, R. M., \& Smith, J. T. (2018). Politics and quality of life. The role of well-being in political outcomes. Cham: Springer. https://doi.org/10.1007/978-3-319-72571-0_6

Publisher's Note Springer Nature remains neutral with regard to jurisdictional claims in published maps and institutional affiliations. 